\title{
Interpretations of the Chinese Boxer Rebellion in the Slovenian Press at the Beginning of the $20^{\text {th }}$ Century ${ }^{1}$
}

\author{
Uroš LIPUŠČEK*
}

\begin{abstract}
This essay deals with the Slovene reaction to the military intervention of eight coalition forces in China during the Boxer Rebellion in China in 1900. To Slovenes, China was then seen as a faraway land that had been visited by some Slovene missionaries, noblemen and travellers throughout the past centuries. Nevertheless, much interest was expressed by the Slovene public and press in the events surrounding the Boxer Rebellion. Despite the fact that the Austro-Hungarian military was part of the international coalition that intervened in Chinese internal affairs, the leading Slovene newspapers of the period supported the right of the Chinese people to defend their country against the big powers of the time, who tried to dismember China and enforce the regime of capitulation.
\end{abstract}

Keywords: China, Slovenia, Boxer Rebellion, Austria-Hungary, Tientsin

\section{Izvleček}

Članek obravnava slovenske reakcije na intervencijo osmih koalicijskih sil na Kitajskem med tako imenovano boksarsko vstajo na Kitajskem leta 1900. Za Slovence je bila Kitajska dolgo daljna dežela, ki so jo v teku stoletij obiskali le nekateri slovenski misijonarji, plemiči in popotniki. Kljub temu pa je slovenska javnost dogajanje, povezano z boksarsko vstajo, spremljala $\mathrm{z}$ veliko pozornostjo. Čeprav je bila avstro-ogrska vojska sestavni del mednarodne koalicije, ki je intervenirala v kitajske notranje zadeve, so takratni vodilni slovenski časopisi podpirali pravico Kitajcev, da branijo svojo državo pred velikimi silami, ki so poskušale razbiti Kitajsko in ji vsiliti režim kapitulacije.

Ključne besede: Kitajska, Slovenija, boksarska vstaja, Avstro-Ogrska, Tientsin

\footnotetext{
${ }^{1}$ This paper was presented at the International Symposium on the History of China's Relations with Central \& Eastern European Countries, at the School of European Languages and Cultures, Beijing Foreign Studies University, China, 17-19 October 2013.

* Uroš LIPUŠČEK, PhD, political scientist uroslipuscek@yahoo.com
} 


\section{Introduction}

To Slovenes, one of the smallest nations of Austria-Hungary, China was traditionally seen as a large and mysterious country in Asia encompassing thousands of years of tradition. With the exception of a small number of intellectuals, few of the common people knew very much about China. Despite this fact, the Boxer Rebellion of 1900 against foreign domination of the then global superpowers was met with relatively large interest from the Slovene press and public at the time.

\section{The Status of Slovenes at the End of the $19^{\text {th }}$ Century}

At the end of the $19^{\text {th }}$ century and in the fin de siècle epoch, Slovenes were one of the smallest nations in the Austro-Hungarian Empire, migrating predominantly to the United States. Demographically, Slovenes mainly consisted of farm workers; town dwellers (bourgeoisie) and workers were very small in number. At this time, approximately 1,325,000 people within the western and Austrian half of the monarchy ${ }^{2}$ spoke Slovene as their primary language (Vodopivec 2007, 139). Until the demise of the Habsburg Monarchy (its population at that time was somewhat less than 50 million inhabitants ${ }^{3}$ ), Slovenes had inhabited six crownlands, which were the least economically developed and most passive regions within the Austrian part of many-nationed Austria-Hungary. Despite this, they enjoyed a relatively high level of culture, as "they only lagged behind the Germans, Czechs and Italians in terms of literacy levels." ${ }^{4}$ This is actually quite an unexpected statistic, as Slovenes did not yet have their own university but only a few secondary schools where lessons were held in Slovene.

\footnotetext{
${ }^{2}$ After the introduction of dualism in 1867, Austria-Hungary was formally composed of two partsthe Austrian part of the empire named Cisleithania and the Hungarian kingdom of Transleithania. These two state units had only certain entities in common, namely the Ministry for Foreign Affairs, the Ministry of Defence and the Ministry of Finance. Formally, Kaiser Francis Joseph led the country, who ruled from 1848 to 1917.

${ }^{3}$ In terms of territory, Austria-Hungary was the second largest state in Europe, the first being tsarist Russia. It was the third in terms of population size, following Russia and Germany. It was economically powerful, attested by the fact that it was the fourth largest manufacturer of machine equipment in Europe.

${ }^{4}$ Austria-Hungary recognized 12 official languages, among them also Slovene (Vodopivec 2007, 127).
} 
In those times, Slovenia was primarily seen as a geographical term for those regions that were located at the strategically important axes of Austria-Hungary, between Vienna and the primary Adriatic port of Trieste, where Slovenes were the second largest nationality following Italians. At the time, "Slovenia" did not hold any political connotation, as a political entity by this name would not be formed until 1918. According to Hegel, Slovenia was classified as belonging to the aptly named "unhistorical nations," who were not in possession of their own state. In the revolutionary year of 1848, the programme Zedinjena Slovenija (United Slovenia) was proclaimed, which demanded the unification of all Slovenes into one common crownland, as well as the granting of equal rights to the Slovene language. At first, the rigid Austro-Hungarian Monarchy, namely its German and Hungarian political elites, did not heed much attention to the programme due to the economic and political weakness of the Slovene nation. Later on, when the monarchy was collapsing and during the First World War, when the programme appeared to be continuing and growing in strength, they began to defiantly oppose it. "Slovenia and the Slovenes became the victims of their geopolitical location, particularly as an obstacle in the way of German, namely Austrian, access to the sea and Trieste (Weg zur Adria freihalten - a free path to the Adriatic)"(Lipušček 2003, 11).

In this manner and due to the division of the Slovene nation amongst various crownlands, as well as Slovenia's geostrategic position, the programme for development of autonomy was not possible up until the end of the $19^{\text {th }}$ century. Despite this, political consciousness was steadily growing, particularly as the end of the First World War was approaching. In the so called Declaration Movement of 1917/1918, the Slovene political parties and the public in general demanded unification of all South Slavs living in the monarchy into a separate state within the monarchy, in which Slovenes would have autonomy. When this was not possible, they demanded an independent state for southern Slavs, in which Slovenes would live as a nation with equal rights. This happened with the establishment of the Kingdom of Serbs, Croats and Slovenes (SHS) in December 1918. Even prior to the establishment of the Kingdom of Serbs, Croats and Slovenes in December 1918, Slovenes had become a political nation. They were practically independently represented at the Versailles Peace Conference in 1919, during which large powers weaved the destiny of not only Europe, but practically the entire world. Slovenes, which had at this point just been incorporated into a new state (SHS), as well as the Chinese, with their nation's thousand year long tradition, which the imperialist forces tried at all costs to break at the end of the 
$19^{\text {th }}$ century, were the losers at Versailles. A third of ethnic Slovene territory was annexed to Italy after the First World War-with the USA President Wilson's blessing; likewise, the Chinese province of Shandong, which was occupied by German imperialists, was "given" to Japan by Wilson's consensus. The world's most populous country, China, and one of Europe's smallest nations, Slovenia, were to share the same destiny on this particular occasion.

\section{Status of China at the End of the $19^{\text {th }}$ Century}

Until the 19th century, namely until the era of imperialism, China enjoyed an autonomous existence, which was more or less closed to foreigners, who were at the time perceived by the Chinese as barbarians. The first large-scale conflict between the Chinese and the "foreign devils" (yang guizi), which referred primarily to Europeans "manifested itself at the turn of the $19^{\text {th }}$ century, when English merchants and politicians would not let go of the idea of achieving a market monopoly in this country of enormous proportions, as soon as possible and at any cost" (Rošker 1992, 156). Because there was no particular demand in China for English products, especially their main product, textile, English traders (with the support of their government) began exporting opium to China, which they declared was a source of happiness. The Chinese were familiar with opium, as it was used for medicinal purposes; it only began to be widely used as a drug alongside the increase of its import (Saje 1994, 29). After a long period of hesitation and fear, in 1839, Emperor Daoguang decided to break off this dangerous trade, which had already left its toll and showed negative consequences on Chinese society. This led to the so-called Opium Wars (1839 and 1856), which China lost.

The consequences of various peace treaties (Treaty of Nanjing in 1842, Treaty of Tientsin in 1858 and Convention of Peking in 1860) were extremely dire. At this point, China became a vassal to European imperialist powers, as it was forced to concede their demands, which significantly affected China's sovereignty. The strategically important island of Hong Kong was given to the British; ports were opened to British traders; the opium trade was reinstated; foreigners obtained free access to travel within China; Catholic missionaries began re-baptising the 
Chinese population, which was another means of Western penetration. ${ }^{5}$ Foreigners were given special extraterritorial rights which meant that in the case of any wrongdoing, their domestic courts had jurisdiction over the case and not Chinese courts under Chinese law. In international law, this system is known as a "regime of capitulation." China had actually already fallen under such a regime in 1689 with the Treaty of Nerchinsk, with which it ended the Sino-Russian border dispute. "This contract is the first written agreement that China ever signed with any of the large European powers, it is also the first of the unequal contracts in which China gave concessions to their adversaries, without demanding concessions in return" (Rošker 1992, 154). Colonial powers forged many other similar agreements, which led to a division into "spheres of interest." China was then divided up into trading spheres, giving each competing state exclusive trading rights in a particular area; it is clear that China was a sovereign and united county on paper only.

Tsarist Russia additionally used this bully diplomacy in the expansion of its empire in Asia. Another of its victims was also Iran. This is seen in the example of the word "capitulation" (kapitulasyum), which has its roots in the Treaty of Turkmenchay forged in 1828, which led Iran to be highly dependent on Russia. It granted Russian citizens extraterritorial rights, permanently ceded certain territories to Russia, allowed free trade and denied Iran the right to have a navy in the Caspian Sea, etc. ${ }^{6}$

At the end of the $19^{\text {th }}$ century, it seemed as if it was only a matter of time when European imperialist forces and Japan (the United States had already granted themselves similar rights in a special contract in 1844) would finish off the Chinese state and force it into colonial submission, as they had previously done with Africa and India. Prior to the outbreak of the First World War, China was the last great unconquered prey, which would be attempted to be divided amongst

\footnotetext{
${ }^{5}$ Father Peter Baptist Turk, a Slovene missionary in China, wrote to his family in 1906 with the following message: "[T]he large majority of our town is still pagan. This does not mean that it lacks faith whatsoever or that it lacks worship. Even the wildest of nations have their gods and ways of worship, more so the Chinese, who have a high level of culture. Each village has, if I may call it so, at least one shrine named a pagoda [...] this is where the Chinese face their gods. They are operated by holy men [...] to enlighten these holy men and women with the Evangelical gospel is completely useless work, this is what has been said by old and grey missionaries." (Čeplak Mencin 2012, 58)

${ }^{6}$ More on the capitulation regime in Asia at this time can be found in Lipušček (1982, 79-93). The aforementioned agreement was met with extreme condemnation by the Iranian public. The unacceptable conditions posed by the agreement caused a frenzied mob of Iranians to break into the Russian legation in Persia and kill the Russian Ambassador Aleksander Sergejevič Gribojedov and his colleagues.
} 
imperialist and colonial superpowers. European and Japanese colonialists transformed China into an independent, semi-colonial state.

English colonialists were particularly aggressive, as they acquired Hong Kong and controlled the majority of trade. They were followed by Russia, which basically occupied the province of Manchuria, opposed by Japan. This led to a war between Russia and China in the year 1904, which Russia lost. In 1897, German imperialists used the murder of two missionaries in order to grant themselves special rights in the Shandong province, Japan took over Korea and Taiwan, etc. China was divided into several spheres of interest in which colonial powers had special rights. The United States, which at the end of the $19^{\text {th }}$ century, had transformed themselves from an agricultural state to a modern industrial society and began to set their ambitions on a global scale and were on the lookout for new potential markets (particularly after their victory in the war with Spain in 1898). At the request of State Secretary John Hay, in 1900, European countries were forced to accept an "open door policy," which stipulated freedom for commercial access and non-annexation of Chinese territory.

The semi-colonial position accepted by the ruling Qing dynasty deepened the political and social crisis in the country to the extreme and contributed to an increase in anti-foreign sentiment amongst the population. In June 1900, the clandestine political organisation (I-ho ch'üan) named the "Boxers" 7 attacked foreign legations in Peking (current-day Beijing). At the beginning, the Boxers wanted to destroy the ruling dynasty, which had ruled China for over 250 years and wanted to get rid of all foreign influence, which they considered a threat to the Chinese way of life and political sovereignty. "When the Empress Dowager backed the Boxers, the Boxers turned solely to ridding China of foreigners." (Rosenberg 2013) By late 1899, bands of Boxers were slaughtering Christian missionaries and Chinese Christians, which they considered to be second class devils. Saje $(1994,41)$ points out that:

Christianity was in opposition to some of the Confucian values and customary habits. Christians enjoyed special legal protection; missionaries were also given other privileges, which is why they were often the targets of violence.

\footnotetext{
${ }^{7}$ Boxers were united in a society of the "righteous and harmonious fists." They were called Boxers because their followers practised martial arts.
} 
All the attacks on missionaries caused the injured Western nations to react harshly and force revenge and collateral damage by gunboats. ${ }^{8}$

Particularly aggressive in Christianization of the Chinese population were the Germans. According to current information, there were no Slovene missionaries present in China during this time. One of the well known missionaries of the time was Father Peter Baptist Turk, who arrived in China at the end of December 1901, when the uprising had already been crushed. ${ }^{9}$

By May 1900 the Boxer Rebellion had come out of the countryside and was being fought in the capital of Peking. To help their fellow countrymen and to protect their interests in China, an international force numbering about 19,000 troops including 2,500 American soldiers stormed Peking in mid August, rescued the legations and forced the imperial court to flee the city. On September 7, 1901, China and 11 other nations signed the Boxer Protocol ending the uprising. ${ }^{10}$ During the Boxer Rebellion and its aftermath in 1899-1901, Austria-Hungary also participated in the Eight Nation Alliance and helped to suppress the uprising. Austria-Hungary, together with Italy, sent the smallest force of any of the combatant nations. Four cruisers and 296 Hungarian enlisted soldiers were dispatched to China. ${ }^{11}$ The leading Slovene newspaper of the time, Slovenec, published many news stories on the topic, which were dispatched from the imperial and royal navy vessel "Zenta."

\footnotetext{
${ }^{8}$ All translations of citations from Slovene are done by the author.

${ }^{9}$ According to Čeplak Mencin (2012, 40-45), the first people from the Slovene ethnic territory to arrive in China were Catholic missionaries. The first to arrive in China is listed as being Franciscan Odorik (Ulrik) Masttiuzzi from Pordenone, therefore, from the very edge of the ethnic Slovene territory. He arrived in Beijing 52 years after Marco Polo. The most prominent missionary from Slovene lands was the Duke Ferdinand Avgustin Haller, who came to China in 1739.

${ }^{10}$ Among the eight power force termed as the "China Relief Expedition" were soldiers from Britain, France, Germany, Italy, Japan, Russia, the USA and Austria-Hungary. The official objective of this multi-national force was to rescue foreign nationals besieged by the Boxers.

${ }^{11}$ Magyar Királyi Központi Statisztikai Hivatal (1907) [Composed 1901]. “A magyar korona területén kivül tartózkodott magyar honos katonák a cs. és kir. közös hügyminiszter által megküldött számlálólapok alapján, összeirási (tartózkodási) helyük szerint” [The number of Hungarian soldiers dispatched abroad according to the re-enlisting papers emitted by the Royal and Imperial joint Minister of Military Affairs sorted by their place of enlisting (dispatchment)]. A magyar szent korona országainak 1901. évi népszámlálása: Harmik rész. A népesség részletes leirása [Census of 1901 in the countries of the Holy Crown: Volume III. The detailed description of the population.] Magyar statisztikai közlemények (in Hungarian) 5 (new ed.). Budapest: Pesti KönyvnyomdaRészvénytársaság, p.31, retrieved January 19, 2011. Summarised from: http://en.wikipedia.org/wiki/ Concessions in_Tianjin (accessed 28 August, 2013).
} 
"On June 18, 1900, the Empress Dowager ordered all foreigners to be killed. Several foreign ministers and their families were killed before the international force could protect them." (Rosenberg 2013) The violence culminated in late June, with the killing of the German and Japanese ministers in Peking. Most foreigners and many Chinese Christians had taken refuge in the foreign legations in Peking, which were besieged by a large force of Boxers supported by Chinese imperial troops. In mid-August, foreign armies numbered around 19,000 soldiers; they stormed Peking, rescued the legations and forced the Imperial Court to flee Peking. In September 1901, China and eleven other nations signed the Boxer Protocol, effectively ending the uprising.

The price China had to pay was very high, indeed. Huge reparations had to be paid for the duration of 39 years, in part for the allied expedition and memorials built in honour of the killed diplomats. Foreign powers also gained concessions to China's mineral wealth and trade. Some member states of this first modern "coalition force" (resemblance to US-Iraqi multinational coalition forces in 2004) also gained some additional concessions.

\section{Austro-Hungarian Concessions in Tientsin}

The strategically very important harbour town south of Peking, Tientsin (currentday Tianjin) was cut into several sections (resembling the Berlin division in 1945). ${ }^{12}$ Eight states had concessions in Tientsin: Britain, France, Germany, Russia, Italy, Belgium, Japan and Austria-Hungary. Austria-Hungary, who participated in the intervention, signed a contract for concession in Tientsin in December 1902, taking the form of compensation. ${ }^{13}$

The British and French had received concessions in Tientsin in 1860, following the Second Opium War. At the end of the $19^{\text {th }}$ century, the first two concession powers were joined by Japan, Germany, Russia, Austria-Hungary, Italy and Belgium. They established their own concessions, ruled by their own laws and officials. The European settlements covered five square miles $\left(13 \mathrm{~km}^{2}\right)$ altogether. Austrian concession territory covered only 150 acres $\left(0.61 \mathrm{~km}^{2}\right)$. The Austrians

\footnotetext{
12 The rivalry between the Japanese and Russians ended in a Russian-Japanese war over Port Arthur in 1904. In less than 14 years, the Allies that had fought together to subdivide China began a bloody war on the battlefields of the First World War.

${ }^{13}$ The main source for this chapter is Lee (2001).
} 
acquired concessions south of the border of the Italian concessions, east of the railway and to the north and west of the Hai River. This area was quite densely populated. "Mainland Chinese historians denounce Austria as an imperialist country that forced thousands of people to move without any compensation." (Lee $2001,77)$ Chinese residents were forced to move away without any compensation. The author of the above mentioned article argues that "most cases of construction recorded in Chinese local newspapers show that the Austrian authorities observed the Treaty and compensated home owners, this contrasts with the beliefs of mainland Chinese historians" (Lee 2001, 78). The Austrian concession had its own theatre, pawnshop, school, barracks, prison, cemetery, hospital, cinema, casino and even lottery. Its citizens were under Austro-Hungarian, not Chinese rule. Austrian authorities under the command of the Austro-Hungarian Consul also introduced a primary school and a business school, modernizing their part of the city. Austrians left their mark on the city, which can still be seen to this day. According to a report filed in 1903 by the Vice Consul to Vienna, Bernauer, out of a total of 25,000 to 30,000 residents, only 3 Europeans lived in this concession and none of them were Austrian. In 1905, there were 60 Austrians living in Tianjin. Another report states that in 1906, the total foreign population in Tianjin was 3,728, this included 72 Austrians.

Austrian authorities sustained one regiment of soldiers in China. Each year, 50 to 70 soldiers returned home and a new regiment came to replace them. The commercial value of this concession for Austria-Hungary was small; in 1906, Vice Consul Bernauer reported to Vienna that "import from Austria was still shamefully small and unimportant" (Lee 2001, 86). Despite the fact that the Suez Canal was opened in the same year when Austria-Hungary received the concession, direct commerce between the most important Austrian port in the Adriatic, Trieste, and the port in Tianjin, never existed. The economic value of the concession for Vienna was therefore a small event, as Austria-Hungary had a surplus in trade with China during this entire period.

The concession lasted until 1917, when the Chinese government joined the Allied forces in the First World War and confiscated the Austrian property in China. For Austria-Hungary, the concession in Tianjin h more or less a symbolic value and meaning. It was a proof that at the time, Austria-Hungary was a large power with the ambition to participate in one of the last major colonial conquests of the world. Nevertheless, according to Lee, in the views of the Chinese, Austria was regarded as a civilized and scientific nation and not a fierce imperialist, which 
can be confirmed by the reporting of the Chinese newspapers at the time. (Lee 2001)

\section{Reactions to the Boxer Rebellion in Slovene Newspapers}

At the turn of the $20^{\text {th }}$ century, three newspapers were being published in ethnic Slovene territory. The most influential of these was the Catholic daily newspaper, Slovenec (the Slovene), which was favoured by the politicians of the strongest Slovene political party Slovenska ljudska stranka or SLS (Slovene People's party), supported by the Catholic Church. The liberally oriented Slovenski narod (Slovene Nation), which frequently criticised the authorities, was published in Maribor, where Germans were predominant. The newspaper Edinost (Unity), which also stood for liberal values, was published in Trieste, the largest port in the monarchy.

International events unfolding at the time were not paid much attention by the Slovene newspapers, as they were all preoccupied with the urgency of reform to the Austro-Hungarian political system in the direction of greater rights for Slavic nations within the monarchy. Despite this, the newspapers followed the events underway in China at the turn of the century with interest.

For example, on $13^{\text {th }}$ June, 1900, in an article entitled "Revolution in China," Slovenec $(1900,1-2)$ wrote that the newest reports on the happening in the sunny and heavenly empire were shocking the entire civilised world. The newspaper went on to report that the greatest danger was posed to the lives and property of European immigrants in China, stating that if the great powers would not be quick to intervene, many would become victims of the fanaticism of the Chinese masses, known in Europe as the "Boxers." 14 In an article from June $26^{\text {th }}$ ("Events in China," $1900,1)$ they conclude that there are no accurate and reliable reports on the events in China, as all connections with Beijing had been cut and only scattered information was coming from Shanghai. Slovenec who was influenced by the Catholic Church was openly supportive of a military intervention by European powers, so that these powers could protect their economic interests in China. In

\footnotetext{
${ }^{14}$ Slovenec reported on 5 September ("Daily News", 1900, 5): "The first Boxer's society in Europe was established in Sava near Jesenice [i.e. a small town in Slovenia]. They do not have a statute yet, nevertheless their aims are publicly known. First, to drink alcohol [...] Clandestine activities take place partly in the woods, partly in an inn." This news was obviously a joke and ironic interpretation of the rebellion.
} 
their view, it was necessary to eliminate the Empress Dowager and the Mandarins, who were turning the people against foreigners. Austria also joined these events when it sent its vessel "Maria Theresa" ${ }^{15}$ to China, stated the newspaper. In fact, four Austro-Hungarian battleships were sent to take part in this international intervention. On July $24^{\text {th }}$, Slovenec ("Events in China", 1900, 1-2) also covered a story that ran in the German newspaper Kölner Zeitung, which states that the Western civilisation must prevail or fall with fire and sword, lead and steel. They stated that if barbarians murdered Europeans, it was in the custom to destroy and burn the entire village of the murderer. They go on to ask if the punishment for Chinese, acting according to primeval custom could be any less brutal, as they had proved to be worse than wild beasts or cannibals. These brash and bold articles were published at a time when the world was flooded with speculation about the Chinese having killed all foreign diplomats and missionaries and foreigners in general, which later turned out to be false and exaggerated.

Trieste's newspaper Edinost, which generally favoured the Chinese, wrote on July $5^{\text {th }}$ under the title "Terror in China" $(1900,1)$ that it was simply not possible to know whether any of our diplomats were still alive, with the conclusion:

Today, we can no longer ask if the Chinese have the right to maintain sovereignty on their own land, today we must face the cruel fact that the Chinese are singlehandedly overruling the international law with their bloody acts carried out on innocent civilians, who are not responsible for the events caused by the global politics.

With particular care, on July $4^{\text {th }}$, Slovenec reported ("Events in China", 1900, 1-3) that following the murder of the German envoy Ketteler, the German Kaiser Wilhelm declared to German soldiers departing to China that:

the Chinese have declared war in the midst of a silent peace [...] the German flag has been offended, the German nation is humiliated. This calls for a harsh punishment, to set an example [...] I will not rest until the German flag does not wave in China, on the walls of the city of Beijing, along with that of other European states.

They also ran a statement from the German Kaiser from Berlin that when they [the Chinese] face their enemy, let them know that there are no excuses, no prisoners.

\footnotetext{
${ }^{15}$ According to Čeplak Mencin $(2012,97)$, the chief commander of Austria-Hungary Navy in this operation was captain Anton Haus from Tolmin. He was in charge of "Maria Theresa."
} 
Fight so that in a thousand years from now, no Chinese person will dare look at a German the wrong way.

The liberal newspaper Slovenski narod took in its July $23^{\text {rd }}$ edition under the title "Austrian War Fanatics" $(1900,2)$ a very critical stand on the brazen speech of the German Kaiser. They felt that the speech of Kaiser Wilhelm II, who in his tension spoke of bloody revenge, had turned "our Great German followers" mad. "Where Germany is, there must also stand our nation! The bloodshed in Peking is only a welcome front for butchery and pillaging for our nationalistic bloodthirsty journalists. What business does Austria have in China?" asked Slovenski narod. "Economic interests are forcing Europe and America to re-open China for foreign trade. But Austria-Hungary does almost no trade with China. Why should our soldiers help to double the profits of English, American and German traders?" In accordance with its anti-colonial stance, in an article entitled "China to the Chinese" on June $20^{\text {th }}(1900,1)$, Slovenski narod wrote that:

the suffering of China at the hands of foreign countries is beyond all boundaries. This would not be tolerated by any country. China is literally being ripped apart $[\ldots]$ a real division of China is taking place $[\ldots]$ thus it is natural that the Chinese nation has begun to fight against the foreign elements, which have flooded their homeland, it is understandable that a revolution geared towards foreigners has begun, that the Empress has stood up and declared an official war.

In its July $30^{\text {th }}$ edition, Slovenski narod in the article "Rallying Cry of German Kaiser" $(1900,1)$ states that the statements of the German Kaiser are in opposition to all the natural feelings of cultured human beings, as the Kaiser called for German military to kill and massacre anything that finds itself by their knives. This was not seen as a fair fight, no more a struggle of man versus man, but mass execution and massacre.

Slovenski narod was also very critical of the role missionaries played in propagating hatred in China. As it concludes on July $9^{\text {th }}$ ("War in China", 1900, 1):

[T] hese people force a faith upon the Chinese people, which they do not understand and which undermines traditional Chinese faith and customs. We need to only think of what might happen if Buddhist missionaries came to us, if they were to try to teach us that our religion were worthless and malignant, if they were to meddle in our domestic political affairs and extend their arms towards our wives and daughters. The nation would kill them, if the government were not to exile them beforehand. 
Given that Slovenes were at that time one of the most devout Catholic nations and that several Slovene missionaries left for China with the blessing of Slovene bishops, the above criticism can be seen as being very brave. Edinost and Slovenski narod were very critical of the zealot Catholic missionaries in China, also due to their anticlerical ideology. It is quite interesting that the Austrian censor did not hinder the publication of such "subversive" thoughts. A relatively critical standpoint towards international military intervention in China was also taken by the Trieste newspaper Edinost. On July $5^{\text {th }} 1900$ (p. 1), the newspaper poses the question of why the Monroe Doctrine should not also be valid for China, transferred from the United States to China. "China to the Chinese" declares Edinost and adds that no nation can accept foreigners to be so aggressive towards them, that they end up as foreigners in their own homeland.

On the whole, leading Slovene newspapers of the time took a relatively critical stand on European military intervention in China. They condemned pogroms and murder of foreign nationals brought about by Chinese forces, particularly the Boxers, but were quick to point out that foreign powers were attempting to divide China due to their own economic interests and that the Chinese people had the right to defend themselves.

\section{Conclusion}

It is a fact that Slovenes, as one of the smallest nations in Europe living on the periphery of the Habsburg Monarchy, understood the essence of events unfolding in China at the turn of the $20^{\text {th }}$ century, both from the economic and political viewpoint. China was defending itself from foreign colonial aggressors that forced on it a capitulation regime and tried to break its tradition of statehood and undermine thousands of years of culture, while also forcing on them a new religion. Slovenes on the other hand had only just begun to be fully aware of their national consciousness and this in a truly political sense. Two of the three leading Slovenian newspapers of that time, liberal Slovenski narod from Maribor and Edinost from Trieste openly sided with the Chinese, while the daily Slovenec who was near the Catholic Church, endorsed the official position. Generally speaking, two leading Slovene newspapers were in opposition to the official government policy of Austria-Hungary, which took part in the military intervention in China, also because of their liberal orientation and very critical anticlerical position 
toward the Catholic Church. This was an act of considerable editorial courage. It is also interesting to note, that the authorities did not censor comments that were diametrically opposed to the official policy of Vienna. This shows that old Austria respected certain basic democratic standards. The small Slovene nation therefore showed a great concern for the liberational aspirations of the Chinese people. The Slovenes fought for similar political aims - for autonomy and self-development (then under Austria-Hungary), which was strongly opposed by the Austrian government who was under the heavy influence of German nationalist parties.

At the Paris Peace Conference at the end of the First World War, Chinese as well as Slovenes found themselves in the same boat, a boat which was to be guided by self-determination of nations and breaking ties with the anchors of old imperialistic practices - a boat to be led by US President Wilson. "Chinese nationalists looked to the U.S. President to usher in a new era of international equality" (Mandela 2007, 99). This did not occur as Wilson surrendered to the socalled old diplomacy. This led to the Chinese loss of the Shandong province for a number of years and the Slovene loss of almost a third of their ethnic territory and a quarter of the entire population. Both nations can be counted as the victims of imperialist greed.

\section{References}

Čeplak Mencin, Ralf. 2012. V deželi nebesnega zmaja: 350 let stikov s Kitajsko. Ljubljana: Založba $/ *$ cf.

Edinost, 1900. 25/151 (5 July).

Lee, Chinyun. 2001. "The short life of the Austrian Concession in Tianjin." Azijske in afriške študije/Asian and African studies 5 (1-2): 74-92.

Lipušček, Uroš. 1982. Iran proti Iranu: Islam - revolucija - Homeini. Ljubljana: Borec.

Lipušček, Uroš. 2003. Ave Wilson: ZDA in prekrajanje Slovenije v Versaillesu 1919-1920. Ljubljana: Sophia.

Mandela, Erez. 2007. The Wilsonian Moment. Oxford: Oxford University Press.

Rosenberg, Jennifer. 2013. "1900 - Boxer Rebellion: A Rebellion in China against All Foreigners.” Accessed August 28. http://history1900s.about.com/od/1900s/qt/boxer. htm.

Rošker, Jana. 1992. Zmajeva hiša: Oris kitajske kulture in civilizacije. Ljubljana: Cankarjeva založba. 
Saje, Mitja. 1994. Zgodovina Kitajske. Od tradicionalne do moderne Kitajske. Obdobje Qing. Ljubljana: Študentska organizacija Univerze v Ljubljani.

Slovenec, 1900. 28/134 (13 June), 28/144 (26 June), 28/150 (4 July), 28/167 (24 July), 28/203 (5 September).

Slovenski narod, 1900. 33/139 (20 June), 33/154 (9 July), 33/166 (23 July), 33/173 (30 July).

Vodopivec, Peter. 2007. Od Pohlinove slovnice do samostojne države: Slovenska zgodovina od konca 18. stoletja do konca 20. stoletja. Ljubljana: Modrijan. 